(c) American Dairy Science Association, 2002.

\title{
Production of Pyroglutamic Acid by Thermophilic Lactic Acid Bacteria in Hard-cooked Mini-Cheeses
}

\author{
G. Mucchetti, F. Locci, P. Massara, R. Vitale, and E. Neviani \\ Istituto Sperimentale Lattiero Caseario \\ Lodi, Italy
}

\section{ABSTRACT}

Pyroglutamic acid is present in high amounts $(0.5 \mathrm{~g} /$ $100 \mathrm{~g})$ in many cheese varieties-and particularly in extensively ripened Italian cheeses such as Grana Padano and Parmigiano Reggiano.

An in vivo model system for cooked mini-cheese production and ripening acceleration was set up to demonstrate the ability of thermophilic lactic acid bacteria, used as a starter, to produce pyroglutamic acid (pGlu). In mini-cheeses stored at 38 and $30^{\circ} \mathrm{C}$ for up to $45 \mathrm{~d}$, all starters tested produced different amounts of pGlu. In descending order of pGlu production, the bacteria analyzed were: Lactobacillus helveticus, Lactobacillus delbrueckii subsp. bulgaricus, Streptococcus thermophilus, and Lactobacillus delbrueckii subsp. lactis.

Evidence for the presence of glutamine to pGlu cyclase activity in lactic acid bacteria was provided. Cell lysates obtained from cultures of $L$. helveticus, $L$. delbrueckii subsp. bulgaricus, L. delbrueckii subsp. lactis, and $S$. thermophilus showed the ability to cyclize glutamine to $\mathrm{pGlu}$, resulting in processing yields from 1.4 to $30.3 \%$, depending on the subspecies. Formation of pGlu from free glutamine appeared to be similar to that observed using a glutamine-glutamine dipeptide substrate. Under the experimental conditions applied, pGlu aminopeptidase activity was only detected in $L$. helveticus. Thus, pGlu formation in long-ripened cooked cheese may depend on the activity of thermophilic lactic acid bacteria.

(Key words: pyroglutamic acid, lactic acid bacteria, cyclase activity)

Abbreviation key: LAB = Lactic Acid Bacteria, NCN $=$ noncasein nitrogen, $\mathbf{p G l u}=$ Pyroglutamic Acid, $\mathbf{P C P}$ = pyrrolidone carboxyl peptidase, PYRase $=$ L-pyroglutamil-peptide hydrolase.

Received: November 9, 2001

Accepted: March 15, 2002.

Corresponding Author: Germano Mucchetti ; email: gmucchetti@ ilclodi.it.

\section{INTRODUCTION}

Pyroglutamic acid (pGlu) (5-oxo-proline), or pyrrolidone carboxylic acid, is found either as a free acid or at the $\mathrm{N}$ terminus of various proteins, and the localization of pGlu at the $\mathrm{N}$ terminus of various bioactive peptides is associated with their biological activity (Awadé et al., 1994), e.g. protecting proteins or peptides against degradation (Van Coillie et al., 1998). The pGlu has been shown to have pharmacological properties (Awadé et al., 1994), e.g. as an excitatory amino acid antagonist (Beani et al., 1990), brain stimulator (Mirzoian et al., 1994), and ansiolitic agent (Beni et al., 1988).

pGlu can also be released in cheese from the $\mathrm{N}$ terminus of proteins and peptides by the activity of pyrrolidone carboxyl peptidase (PCP) or L-pyroglutamil-peptide hydrolase (PYRase) (E.C. 3.4.11.8). PCP has been detected in many bacteria (Awadé et al., 1994; Williams et al., 1997; Laan et al., 1998; Williams and Banks, 1998). The enzymatic synthesis of pGlu by cyclotransferase from glutamic acid or glutamine as precursors has been described for Pseudomonas cruciviae (Akita et al., 1959) and Streptococcus bovis (Chen and Russel, 1989).

As a free acid in the enantiomeric form L, pGlu has been found in large quantities in Parmigiano-Reggiano and Grana Padano cheeses, two typical Italian hardcooked cheeses produced using a natural whey starter composed mainly of thermophilic lactobacilli and ripened for a minimum of 12 and 9 months respectively (Mucchetti et al., 2000). After 2 to 3 mo of ripening, pGlu appeared and progressively increased for up to 24 mo of ripening and $600 \mathrm{mg} / 100 \mathrm{~g}$ of cheese (Panari, 1985; Mucchetti et al., 2000).

That thermophilic lactobacilli are involved in pGlu production is suggested by the low content of pGlu ( 67 $\mathrm{mg} / 100 \mathrm{~g}$ ) found in Bagos, a long-ripened Italian mountain cheese made without starter addition, and by the limited pGlu content $(150 \mathrm{mg} / 100 \mathrm{~g})$ detected in cheese made from starters containing $S$. thermophilus after 5 to 6 mo of ripening (Mucchetti et al., 2000). pGlu content in experimental Grana Padano cheeses made with raw or pasteurised milk was similar (Mucchetti et al., 2000). 
Table 1. pH, salt, and galactose content of mini-cheeses after brining within 24-h of cheese making

\begin{tabular}{lllll}
\hline Starter & Code & $\mathrm{NaCl}$ & Galactose & $\mathrm{pH}$ \\
\hline Commercial whey starter & $\mathrm{SG}$ & $1.29 \pm 0.028^{\mathrm{a}}$ & $0.00^{\mathrm{a}}$ & $5.26 \pm 0.028^{\mathrm{a}}$ \\
L. helveticus & $\mathrm{LH}$ & $1.13 \pm 0.057^{\mathrm{b}}$ & $0.06 \pm 0.014^{\mathrm{a}}$ & $4.78 \pm 0.014^{\mathrm{b}}$ \\
L. delbrueckii subsp. bulgaricus & $\mathrm{LB}$ & $1.51 \pm 0.071^{\mathrm{c}}$ & $0.95 \pm 0.042^{\mathrm{b}}$ & $5.15 \pm 0.042^{\mathrm{c}}$ \\
L. delbrueckii subsp. lactis & $\mathrm{LL}$ & $1.20 \pm 0.028^{\mathrm{ab}}$ & $0.04 \pm 0.006^{\mathrm{a}}$ & $4.89 \pm 0.057^{\mathrm{d}}$ \\
S. thermophilus & $\mathrm{ST}$ & $1.18 \pm 0.042^{\mathrm{ab}}$ & $0.85 \pm 0.028^{\mathrm{c}}$ & $5.42 \pm 0.014^{\mathrm{e}}$ \\
S. thermophilus + L. delbrueckii subsp. bulgaricus & $\mathrm{ST}+\mathrm{LB}$ & $1.26 \pm 0.028^{\mathrm{a}}$ & $0.88 \pm 0.028^{\mathrm{c}}$ & $5.23 \pm 0.028^{\mathrm{ac}}$ \\
\hline
\end{tabular}

${ }^{\mathrm{a}, \mathrm{b}, \mathrm{c}, \mathrm{d}, \mathrm{e}}$ Values in the same column without a common letter are significantly different $(P<0.05)$.

These observations suggest that pGlu formation depends mainly on the whey starter microflora rather than that of raw milk (Mucchetti et al., 2000).

Because of the localization in cytoplasm of those enzymes able to release pGlu from the $\mathrm{N}$ terminus of peptides (Awadé et al., 1994), it can be supposed that these enzymes may be active in the cheese, mainly if bacterial cells undergo lysis. Hence, to release pGlu in cheese, the starter and/or raw milk microflorae must either undergo autolysis or be lysed. In cheese, Gatti et al. (1999) showed the presence of aminopeptidase activities, which are characteristic of thermophilic lactobacilli from whey starters and may be considered as markers of bacterial autolysis.

The presence of aminopeptidase pGlu activity has been rarely shown in thermophilic lactobacilli and streptococci. Williams and Banks (1997) and Williams et al. (1998) detected aminopeptidase pGlu activity by cell lysates from two L. helveticus strains, but did not find it in L. delbrueckii subsp. bulgaricus and L. delbrueckii subsp. lactis.

This work aims to show the ability of thermophilic lactic acid bacteria (LAB) to form pGlu both in vivo and in vitro.

\section{MATERIALS AND METHODS}

In order to verify the in vivo role played by thermophilic LAB in pGlu production in hard long ripened cheeses, a model was set up using mini-cheeses made with different starters of defined composition and ripened at high temperatures to accelerate the bacterial cell lysis, and consequently the formation of pGlu.

\section{Starters Used for the Production of Mini-cheeses}

For the cheeses coded LH, LB, and LL, three singlespecies LAB starters, obtained by respectively mixing 4 strains of Lactobacillus helveticus 3, 7, 22 and 23 (LH), 5 strains of Lactobacillus delbrueckii subsp. bulgaricus 2, 10, 15, 17 and 19 (LB), and 5 strains of Lactobacillus delbrueckii subsp. lactis 14 to 18 (LL), from the ILC collection, were prepared (Table 1). A commercial Streptococcus thermophilus culture (IDC, Centro Speri- mentale Latte, Zelo Buon Persico, Milano, Italy) as a direct-to-vat starter, and $S$. thermophilus and $L$. delbrueckii subsp. bulgaricus cultures (IDC, Centro Sperimentale Latte) were used for mini-cheeses coded ST and ST+LB. For the production of the reference minicheese (SG), a common commercial whey starter for industrial Grana Padano cheese making, containing undefined thermophilic lactobacilli (SierGrana, Alce, Novara, Italy), was used.

\section{Cheese Vat Milk Processing Step}

After a series of preliminary trials (not described here) aimed at setting up a production technique, six cheesemaking trials were carried with the aforementioned starters.

$330 \mathrm{~kg}$ of milk partially skimmed ( $2.4 \%$ fat) by spontaneous creaming was pasteurized directly in a coagulation vat using the following thermal cycle: the heating time from 15 to $70^{\circ} \mathrm{C}$ was $15 \mathrm{~min}$, the holding time at $70^{\circ} \mathrm{C}$ was $1 \mathrm{~min}$, and the cooling time from $70^{\circ} \mathrm{C}$ to the renneting temperature of $32^{\circ} \mathrm{C}$ was $22 \mathrm{~min}$. After adding $6 \mathrm{~g}$ of lysozyme (Clerici, Cadorago-Como, Italy) and the starter, coagulation occurred within 12 to 14 min by adding $4 \mathrm{~g}$ calf rennet (Titre 1:125,000, Clerici, Cadorago-Como, Italy) per $100 \mathrm{~kg}$ of milk. Following the Grana cheese making process (Neviani and Carini, 1994), after fine curd breakage and cooking at $53^{\circ} \mathrm{C}$, the cooked curd was extracted to make mini-cheeses.

\section{Curd Extraction and Molding}

Each mini cheese was made from a 4-kg mixture containing curd and whey which was taken from the bulk maintained under stirring, and placed directly into a baby Gouda mold. The molds were provided with a net for rapid whey drainage. A lid was put on the mold so that mini-curds could be turned over without coming into contact with the operator's hands. Twenty cheeses were obtained from each vat. The overall curd extraction time to obtain the mini-cheeses was $5 \mathrm{~min}$, and the remaining curd yielded a whole cheese. The minicurds in the molds were placed in a forced-air oven at $40^{\circ} \mathrm{C}$ for $18 \mathrm{~h}$ and then immersed in saturated brine at 
$40^{\circ} \mathrm{C}$ for $1 \mathrm{~h}$. After removal from the brine, the minicheeses were kept in the oven for 60 to 90 min to dry the residual brine on the surface. The dried cheeses were then immersed in a fused paraffin bath (hardening interval 68 to $74^{\circ} \mathrm{C}$ ) to make a hydrophobic barrier, thus decreasing loss of weight by evaporation during the subsequent ripening step. Each cheese weighed approximately $300 \mathrm{~g}$.

\section{Ripening}

Cheeses were weighed prior to ripening, and those exceeding $\pm 5 \%$ of the average weight were rejected. To accelerate bacterial cell lysis, and consequently the cheese ripening and pGlu formation, the mini-cheeses, subdivided into 6-unit batches for each incubation temperature, were ripened in air ovens at $15^{\circ}, 30^{\circ}$, and $38^{\circ} \mathrm{C}$ for up to $45 \mathrm{~d}$.

\section{Cheese Composition Analyses}

The total solids content of the mini-cheeses was determined according to IDF No 4A:1982 standard (IDF, 1982). The $\mathrm{NaCl}$ content of cheese was determined according to IDF No 17A: 1972 standard (IDF, 1972).

To measure the acceleration of cheese ripening due to storage temperature, the total nitrogen, noncasein nitrogen (NCN), and NPN of the reference cheeses (SG), were evaluated according to Gripon et al. (1975).

The pGlu, lactic acid, and galactose contents of the cheeses were determined by HPLC with the method described by Bouzas et al. (1991) for the simultaneous analysis of sugars and organic acids in cheese, using an Aminex HPX-87 column (Bio-Rad Laboratories, Richmond, CA) and ultraviolet and refractive index detectors in series.

\section{Microbiological Characteristics}

Thermophilic LAB counts were carried out in MRS agar (Biokar, Beauvais, France) with anaerobic incubation of the poured plates at $42^{\circ} \mathrm{C}$ for $48 \mathrm{~h}$. Total coliform counts were carried out in Violet Red Brilliant Agar (Oxoid, Basingstoke, UK) with incubation at $30^{\circ} \mathrm{C}$ for $24 \mathrm{~h}$. Eumycetic microflora count was carried out in Oxytetracycline Glucose Yeast Extract Agar (Oxoid), and incubated at $25^{\circ} \mathrm{C}$ for $5 \mathrm{~d}$.

\section{Evaluation of Cell Lysis by Determination of Aminopeptidase Activity}

To verify the influence of storage temperature on the degree of starter bacterial cell lysis, the amount of lysis was evaluated by determining the aminopeptidase ac- tivity with lysine $\beta$-naphthylamide as a substrate. The enzymatic activity was only determined in cheeses produced with single-species multiple-strain cultures after 12 and $45 \mathrm{~d}$ of storage at $12^{\circ}, 30^{\circ}$, and $38^{\circ} \mathrm{C}$ and was ascertained by the previously described method (Gatti et al., 1999).

\section{Detection of Cyclase and Aminopeptidase pGlu Activities}

In order to verify the ability of LAB to produce pGLu in vitro, the cyclase and peptidase activities of single strains of thermophilic lactobacilli and S. thermophilus, chosen among those used in the formulation of the starters, have also been evaluated.

L. helveticus 3, L. delbrueckii subsp. lactis 18, L. delbrueckii subsp. bulgaricus 10 and S. thermophilus A, isolated from the commercial blend used as a starter, were cultured in 400-ml MRS and M17 (Oxoid, UK) broth at $42^{\circ} \mathrm{C}$ after incubation overnight. After centrifugation at $11,600 \times \mathrm{g}$ at $4^{\circ} \mathrm{C}$ for $30 \mathrm{~min}$, the cells were washed twice using $50 \mathrm{~m} M$ glycerophosphate buffer, $\mathrm{pH}$ 7.0. The pellet was resuspended in $10 \mathrm{ml}$ of 10 $\mathrm{m} M$ Tris Ethanol Amine (TEA) buffer, $\mathrm{pH}$ 7.0, then subjected to treatment in a French Press apparatus (20 K Manual Fill cell pressure, Spectronic Instruments, Analytical Control SpA, Cinisello Balsamo, Milano, Italy) at $4^{\circ} \mathrm{C}$ and $128 \mathrm{MPa}$ for 15 (first run) and $5 \mathrm{~min}$ (second run). The cell lysate was frozen at $-20^{\circ} \mathrm{C}$.

\section{Cyclase Activity: Conditions for Reaction and Determination of pGlu}

Cell lysate $(0.2 \mathrm{ml})$ was added to $1.8 \mathrm{ml}$ of either $7.85 \mathrm{mg} / \mathrm{ml}$ of glutamine or $7.7 \mathrm{mg} / \mathrm{ml}$ of glutamineglutamine dipeptide (Fluka Chemie AG, Sigma-Aldrich, Milano, Italy) dissolved in $10 \mathrm{~m} M$ TEA buffer, $\mathrm{pH}$ 8.6. The enzyme-substrate mixtures were then incubated at $42^{\circ} \mathrm{C}$ for 24 and $48 \mathrm{~h}$. After ultrafiltration by centrifugation at $3000 \mathrm{~g}$ at $25^{\circ} \mathrm{C}$ for $95 \mathrm{~min}$ in Centriplus $3 \mathrm{MW}$ microconcentrators with a 3000-dalton cutoff (Amicon, Passirana di Rho, Milan, Italy), the pGlu content of the filtrate was determined by HPLC, as described above.

\section{Aminopeptidase pGlu Activity}

Using the same cell lysates as those used to determine cyclase activity, the PYRase activity was determined by both spectrophotometry, using pGlu $\beta$-naphthylamide as a substrate as previously described (Gatti et al., 1999), and by high resolution chromatography. Cell lysate $(0.1 \mathrm{ml})$ was added to $0.9 \mathrm{ml}$ of solution containing $0.22 \mathrm{mg}$ of pGlu-alanine peptide (Fluka) dis- 
solved in $10 \mathrm{~m} M$ TEA buffer, $\mathrm{pH}$ 7.0. The enzyme-substrate mixture was incubated at $42^{\circ} \mathrm{C}$ for $24 \mathrm{~h}$. After ultrafiltration by centrifugation at $3000 \mathrm{~g}$ at $25^{\circ} \mathrm{C}$ for $95 \mathrm{~min}$ in a Centriplus $3 \mathrm{MW}$ microconcentrator with a 3000-dalton cutoff (Amicon), the pGlu content of the filtrate was determined by HPLC as described above.

\section{Statistical analysis}

Data from chemical cheese composition were evaluated for their significance $(P<0.05)$ with one-way ANOVA, by the software "Analyse-It+General Statistics vsn. 1.62" for Microsoft Excel (Analyse-It Company, $\mathrm{UK})$.

\section{RESULTS AND DISCUSSION}

\section{Mini-cheese Production}

Except for the commercial SierGrana whey culture, all the mini-cheeses were made using starters containing defined thermophilic LAB. In 24-h cheeses LB and $\mathrm{ST}+\mathrm{LB}$, made using the starter containing $L$. delbrueckii subsp. bulgaricus and/or S. thermophilus, 0.95 and $0.85 \%$ nonfermented galactose was still present, respectively. Within $18 \mathrm{~h}$ of incubation at $40^{\circ} \mathrm{C}$, the $\mathrm{pH}$ of mini-cheeses decreased to a range of 4.78 to 5.42 , depending on the starter used (Table 1). The decrease in curd $\mathrm{pH}$ obtained with $L$. helveticus and L. delbrueckii subsp. lactis was higher than that occurring in Grana Padano. Despite the unusual temperature conditions (Giraffa et al., 1998), the decrease in $\mathrm{pH}$ demonstrated that the starter microflora was also viable under the above growth conditions, as confirmed by counts (see section). Processes for extraction, curd molding and ripening at different temperatures were developed, allowing us to obtain six series of mini cheeses with an average total solids content of $58.59 \pm 0.61$. Only the cheese LL, produced with $L$. delbrueckii subsp. lactis as a starter, showed a significantly different total solid content $(P<0.05)$ (Table 2$)$.

Brining at $40^{\circ} \mathrm{C}$ (to accelerate the salt penetration without breaking the successive thermal cycle of ripening for the cheeses incubated at $38^{\circ} \mathrm{C}$ ) allowed us to obtain cheeses having an average $\mathrm{NaCl}$ content of $1.26 \%$ \pm 0.15 , which is similar to the amount usually found in Grana Padano and Parmigiano-Reggiano cheeses. The brining increased the differences in total solids contents among the six lots of mini-cheeses (Table 2). Ripening at high temperatures forced us to use cheese rind paraffin to reduce moisture loss by evaporation, especially for cheeses ripened at 30 and $38^{\circ} \mathrm{C}$. However, the variation in evaporation for the six lots of mini-cheeses resulted in different amounts of total solids among the cheeses ripened at the three temperatures (Table 2).
Means for the total solids content of cheeses within 45 $\mathrm{d}$ of ripening ranged from the initial value of $58.59 \% \pm$ 0.61 to $60.87 \pm 0.97,64.49 \pm 2.35$ and $66.05 \% \pm 1.89$ for the cheeses ripened $45 \mathrm{~d}$ at 15,30 and $38^{\circ} \mathrm{C}$, respectively. These differences in the total solids content of mini-cheeses during ripening fit well with those of traditional ripening of Grana Padano and ParmigianoReggiano cheeses which have total solids values around 58 to $60 \%$ prior to salting and around 67 to $70 \%$ after $12 \mathrm{mo}$.

\section{Microbiological Characteristics of Mini-cheeses}

It was possible to distinguish between the development of the lactic microflora added with the starter during the first $24 \mathrm{~h}$ of cheesemaking and the development at the end of the ripening period at the three different temperatures (Table 3). Cheeses LH and LB, made from $L$. helveticus and $L$. delbrueckii subsp. bulgaricus, showed decreased values for cfu/g after $24 \mathrm{~h}$, compared with those found in cooked curds. Conversely, the other mini-cheeses showed a progressive increase in the lactic microflora from the starter. The ripening temperature sharply decreased the viable microbial population in cheeses ripened at $38^{\circ} \mathrm{C}$, except for those made from commercial starters (containing undefined thermophilic lactobacilli, or a mixture of $S$. thermophilus and L. delbrueckii subsp. bulgaricus), where cell death was definitely lower. The presence of nonfermented galactose in the 24 -h cheeses ST, LB and ST+LB made with starters containing galactose-negative $L$. delbrueckii subsp. bulgaricus or S. thermophilus strains (Kandler and Weiss, 1986), together with the absence of coliform and eumycetic microflora, demonstrated that the prevailing microflora of mini-cheeses was supplied by starters.

\section{Evaluation of Accelerated Ripening in Reference Cheeses}

Storage of reference cheeses (SG) at $30^{\circ}$ and $38^{\circ} \mathrm{C}$ resulted in a considerable increase in the NCN/NT $(21.5$ vs. $11.3 \%$ ) and NPN/NCN (100 vs. $91.4 \%)$ ripening indices compared with cheeses ripened at $15^{\circ} \mathrm{C}$ (Table 4). The NCN/NT index for the cheeses stored at $38^{\circ} \mathrm{C}$ after $45 \mathrm{~d}$ increased to $23 \%$. This corresponds to the value for Parmigiano-Reggiano cheese after 8 mo (Panari et al., 1988). In addition, an NPN/NCN ratio close to one suggests that peptides deriving from the action of proteases on casein are quantitatively hydrolyzed to oligopeptides and amino acids by peptidil-peptidases and/ or aminopeptidases. Acceleration in ripening was induced by a faster release of intracellular enzymes to the cheese paste. 
Table 2. Influence of brining and ripening temperatures on the increase of total solids in mini-cheeses.

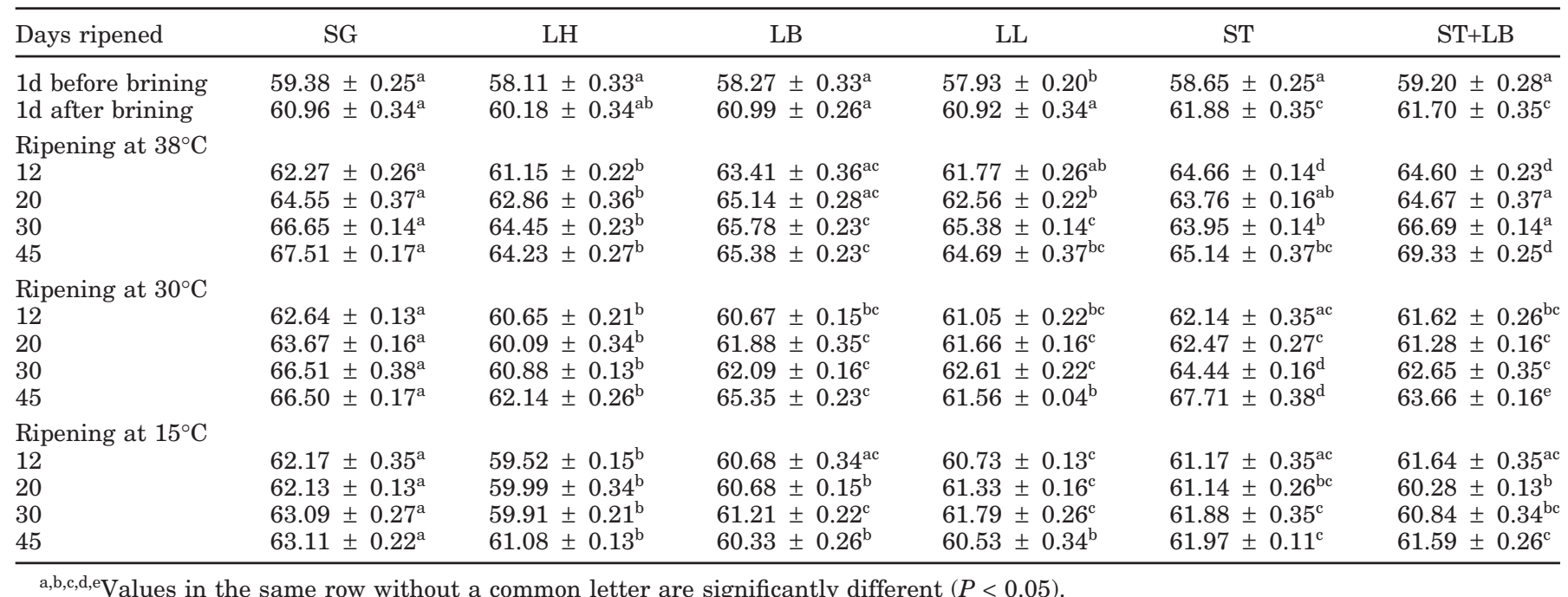

a,b,c,d,e Values in the same row without a common letter are significantly different $(P<0.05)$.

\section{Evaluation of Cell Lysis}

Cheeses ripened at $30^{\circ} \mathrm{C}$ always showed a higher residual aminopeptidase activity on lysine $\beta$-naphthylamide than those ripened at $15^{\circ} \mathrm{C}$. Cheeses stored at $38^{\circ} \mathrm{C}$ showed the higher activity after $12 \mathrm{~d}$, while the activity lessened after $45 \mathrm{~d}$. Extending the storage to $45 \mathrm{~d}$ at $38^{\circ} \mathrm{C}$ likely reduced the detectable residual enzymatic activity, which was generally lower than that determined in cheeses stored at 30 and $15^{\circ} \mathrm{C}$ (Table 5 ). We suggest that this reduction cannot be due to a reduced bacterial lysis, but to a reduction in stability of some enzymes able to hydrolyse lysine $\beta$-naphthylamide. Cheese ripening at high temperatures accelerated cell lysis, as previously observed in vitro (Long et al., 1999) and in hard semicooked cheeses (Gatti et al., 2000).

\section{pGlu Production}

Ripening cheese at $38^{\circ} \mathrm{C}$ and $30^{\circ} \mathrm{C}$ accelerated pGlu production. In all the mini-cheeses, pGlu was detectable after $12 \mathrm{~d}$ incubation at $38^{\circ} \mathrm{C}$ (Table 6). Ripening at $30^{\circ} \mathrm{C}$ also accelerated pGlu production in all cheeses except for cheese ST. ST was made using the starter containing $S$. thermophilus, and pGlu did not appear until after $20 \mathrm{~d}$. In the mini-cheeses, L. helveticus and, to a smaller extent, L. delbrueckii subsp. bulgaricus and $S$. thermophilus formed pGlu the easiest. pGlu production was comparable to that detected in the reference cheese (SG) made using a commercial whey starter containing undefined thermophilic lactobacilli. L. delbrueckii subsp. lactis showed much less of an ability to form pGlu. The combination of $L$. delbrueckii subsp. bulgaricus and $S$. thermophilus did not synergistically enhance pGlu formation. In the cheeses ripened at $15^{\circ} \mathrm{C}$, pGlu production was absent or negligible until $\mathrm{d}$ 30 , and after $45 \mathrm{~d}$ pGlu content was still lower than 40 $\mathrm{mg} / 100 \mathrm{~g}$. Using the pGlu content as a ripening marker (Panari, 1985; Mucchetti et al., 2000), mini-cheese ripening at $38^{\circ} \mathrm{C}$ for $45 \mathrm{~d}$ corresponded to 10 to $11 \mathrm{mo}$ of ripening under standard conditions. The importance of the thermophilic lactic microflorae for pGlu production

Table 3. Thermophilic lactic acid bacteria growth on MRS agar during the first $24 \mathrm{~h}$ of mini-cheese production and after $45 \mathrm{~d}$ of ripening at temperature of $15^{\circ}, 30^{\circ}$, and $38^{\circ} \mathrm{C}$.

\begin{tabular}{|c|c|c|c|c|c|c|}
\hline \multirow[b]{2}{*}{ Code } & \multirow[b]{2}{*}{ Milk + starter } & \multirow[b]{2}{*}{ Cooked curd } & \multirow[b]{2}{*}{$24 \mathrm{~h}$} & \multicolumn{3}{|c|}{$\begin{array}{c}\text { Cheese aged } \\
45 \mathrm{~d}\end{array}$} \\
\hline & & & & $15^{\circ} \mathrm{C}$ & $30^{\circ} \mathrm{C}$ & $38^{\circ} \mathrm{C}$ \\
\hline $\mathrm{LH}$ & $9.90 \mathrm{E}+06$ & $6.48 \mathrm{E}+07$ & $2.43 \mathrm{E}+06$ & $1.73 \mathrm{E}+06$ & $5.29 \mathrm{E}+06$ & $2.47 \mathrm{E}+05$ \\
\hline LL & $3.70 \mathrm{E}+06$ & $2.08 \mathrm{E}+07$ & $1.77 \mathrm{E}+08$ & $4.47 \mathrm{E}+06$ & $1.00 \mathrm{E}+04$ & $1.00 \mathrm{E}+04$ \\
\hline $\mathrm{LB}$ & $3.15 \mathrm{E}+06$ & $3.96 \mathrm{E}+07$ & $4.00 \mathrm{E}+06$ & $1.85 \mathrm{E}+06$ & $1.38 \mathrm{E}+06$ & $1.00 \mathrm{E}+04$ \\
\hline $\mathrm{ST}$ & $5.44 \mathrm{E}+06$ & $1.40 \mathrm{E}+08$ & $1.00 \mathrm{E}+08$ & $5.34 \mathrm{E}+06$ & $3.83 \mathrm{E}+06$ & $3.87 \mathrm{E}+04$ \\
\hline $\mathrm{ST}+\mathrm{LB}$ & $3.10 \mathrm{E}+05$ & $6.06 \mathrm{E}+06$ & $1.49 \mathrm{E}+08$ & $3.36 \mathrm{E}+06$ & $1.34 \mathrm{E}+07$ & $1.68 \mathrm{E}+06$ \\
\hline SG & $9.67 \mathrm{E}+05$ & $2.94 \mathrm{E}+06$ & $2.22 \mathrm{E}+07$ & $1.69 \mathrm{E}+06$ & $2.39 \mathrm{E}+06$ & $2.96 \mathrm{E}+06$ \\
\hline
\end{tabular}


Table 4. Total nitrogen (TN), noncasein nitrogen (NCN), nonprotein nitrogen (NPN) and ripening indices of the reference mini-cheeses (SG) after $30 \mathrm{~d}$ of ripening at temperature of $15^{\circ}, 30^{\circ}$, and $38^{\circ} \mathrm{C}$

\begin{tabular}{lllllc}
\hline Ripening temperature & Total Nitrogen & NCN & NPN & $\begin{array}{l}\text { NCN/TN } \\
\%\end{array}$ & $\begin{array}{l}\text { NPN/NCN } \\
\%\end{array}$ \\
\hline${ }^{\circ} \mathrm{C}$ & $\mathrm{g} / 100 \mathrm{~g}$ & $\mathrm{~g} / 100 \mathrm{~g}$ & $\mathrm{G} / 100 \mathrm{~g}$ & & \\
38 & 5.32 & 1.15 & 1.15 & 21.5 & 100 \\
30 & 5.25 & 0.95 & 0.94 & 18.0 & 98.9 \\
15 & 5.12 & 0.58 & 0.53 & 11.3 & 91.4 \\
\hline
\end{tabular}

in Grana Padano and Parmigiano-Reggiano cheeses was confirmed by the fact that the average pGlu production in the mini-cheeses was comparable to that obtained in reference mini-cheeses made with commercial whey starters containing undefined thermophilic lactobacilli and in commercial mature Grana Padano cheese. Differences in activities between the genera and/or species may help understand the differences observed in pGlu content between Grana Padano cheeses having the same age and produced using different whey starters (data not shown).

\section{Detection of Cyclase Activity in Thermophilic LAB}

The late appearance of pGlu in Grana Padano and Parmigiano-Reggiano cheeses after at least 2 mo of ripening may depend on intracellular localization of the enzymatic systems involved in pGlu formation and a lack or limited presence of its precursors. Intracellular localization of common pyrase and cyclase enzymes is reported in the literature (Awadé et al., 1994), whereas partial, incomplete information is available on pyrases of LAB (Williams and Banks, 1997, Williams et al., 1998; Laan et al., 1998).

This work confirmed the association of glutamine to pGlu cyclase activity in LAB. We verified whether cell lysates produced pGlu from either free glutamine or glutamine-glutamine dipeptide in cultures of the strains L. helveticus3, L. delbrueckii subsp. bulgaricus 10, L. delbrueckii subsp. lactis 18 and S. thermophilus A (Table 7). Cyclization of free glutamine in vitro appeared to be similar to that observed using glutamineglutamine peptide as a substrate. Hence, under the

Table 5. Residual aminopeptidase activity on lysine $\beta$-naphtylamide detected in cheeses produced with single species-multiple strain starter after 12 and $45 \mathrm{~d}$ of ripening at temperature of $15^{\circ}, 30^{\circ}$, and $38^{\circ} \mathrm{C}$

\begin{tabular}{llllllll}
\hline & \multicolumn{3}{c}{$12 \mathrm{~d}$} & & \multicolumn{3}{c}{$45 \mathrm{~d}$} \\
\cline { 2 - 4 } \cline { 6 - 8 } Starter & $15^{\circ} \mathrm{C}$ & $30^{\circ} \mathrm{C}$ & $38^{\circ} \mathrm{C}$ & & $15^{\circ} \mathrm{C}$ & $30^{\circ} \mathrm{C}$ & $38^{\circ} \mathrm{C}$ \\
\hline LH & 1.419 & 1.485 & 1.6 & & 1.038 & 1.577 & 1.37 \\
LL & 0.112 & 0.161 & 0.209 & & 0.136 & 0.31 & 0.30 \\
LB & 0.334 & 0.517 & 0.544 & & 0.412 & 0.615 & 0.33 \\
ST & 0.112 & 0.191 & 0.02 & & 0.122 & 0.231 & 0.03 \\
\hline
\end{tabular}

conditions applied, conversion of glutamine to pGlu varied between 1.4 and $30.3 \%$. L. helveticus 3, L. delbrueckii subsp. bulgaricus 10 , and S. thermophilus A all showed a similar ability to form pGlu, whereas $L$. delbrueckii subsp. lactis 18 had a much lesser ability.

It is still not possible, based on these data, to establish if pGlu in cheese originated from free glutamine (and/or glutamic acid) and/or from peptides having $\mathrm{N}$-terminal glutamine. pGlu precursors in cheese have not yet been clearly identified. During Grana Padano cheese ripening (Borghi, 1999), glutamic acid accumulates in the free amino acid fraction up to a relative percentage of about $30 \%$, which is far beyond the relative percentage of glutamic acid in casein [about 10\% (Alais, 1984)]. Conversely, a decrease in the glutamine content to values lower than $1 \%$ was observed in the same free fraction. Identification of peptides in Parmigiano-Reggiano cheese (Ferranti et al., 1997) showed a considerable amount of peptides, which had N-terminal glutamic acid and/or glutamine residue removable by aminopeptidase action.

\section{Aminopeptidase pGlu Activity}

Under experimental conditions, no aminopeptidase activity was detected using pGlu $\beta$-naphthylamide as a substrate. L. helveticus 3 was the only lysate that

Table 6. Kinetics of pGlu formation in cheeses produced with different starters and ripened at $15^{\circ}$ (usual ripening temperature), $30^{\circ}$, and $38^{\circ} \mathrm{C}$. Data expressed as $\mathrm{mg}$ pGlu/100 g total solids.

\begin{tabular}{lrrrrrr}
\hline Days & SG & LH & LB & LL & ST & ST+LB \\
\hline Ripening at $38^{\circ} \mathrm{C}$ & & & & & & \\
12 & 325.5 & 223.3 & 223.9 & 74.8 & 102.5 & 151.1 \\
20 & 403.0 & 392.9 & 336.7 & 123.7 & 287.6 & 166.0 \\
30 & 515.6 & 531.7 & 441.5 & 216 & 349.2 & 281.0 \\
45 & 593.0 & 674.4 & 525 & 221.9 & 510.7 & 516.1 \\
Ripening at $30^{\circ} \mathrm{C}$ & & & & & & \\
12 & 76.5 & 75.5 & 98.4 & 15.4 & 0.1 & 29.4 \\
20 & 186.2 & 187.2 & 157.9 & 88.2 & 73.8 & 64.7 \\
30 & 364.8 & 297.6 & 275.9 & 180.2 & 190.7 & 90.3 \\
45 & 409.0 & 542.3 & 404.7 & 204.9 & 397.3 & 301.4 \\
Ripening at $15^{\circ} \mathrm{C}$ & & & & & & \\
12 & 0.0 & 0.1 & 0.1 & 0.1 & 0.1 & 0.1 \\
20 & 5.0 & 0.1 & 0.1 & 0.1 & 0.1 & 0.1 \\
30 & 20.2 & 0.1 & 6.3 & 0.1 & 0.1 & 0.1 \\
45 & 37.2 & 6.5 & 23.8 & 0.1 & 0.1 & 0.1 \\
\hline
\end{tabular}


Table 7. Glutamine and glutamine-glutamine to pGlu cyclase activity detected in four strains of thermophilic lactic acid bacteria after incubation of bacterial lysate at $42^{\circ} \mathrm{C}$ for 24,30 , and $48 \mathrm{~h}$. Data expressed as mg $\mathrm{pGlu} / \mathrm{ml}$ and percentage of conversion of glutamine and glutamine-glutamine to pGlu.

\begin{tabular}{|c|c|c|c|c|c|}
\hline \multirow[b]{3}{*}{ Strain } & \multirow{3}{*}{$\begin{array}{l}\text { reaction time } \\
\text { (h) }\end{array}$} & \multicolumn{2}{|c|}{ Gln } & \multirow{2}{*}{\multicolumn{2}{|c|}{ gln-gln }} \\
\hline & & \multirow{2}{*}{$\underset{\mathrm{pGlu} / \mathrm{ml}}{\mathrm{mg}}$} & \multirow[b]{2}{*}{$($ pglu/gln $) \%$} & & \\
\hline & & & & mg pGlu/ml & (pGlu/gln-gln)\% \\
\hline \multirow[t]{3}{*}{ LH3 } & 24 & 0.31 & 11.17 & 0.17 & 5.98 \\
\hline & 30 & 0.75 & 27.02 & 0.68 & 23.94 \\
\hline & 48 & 0.85 & 30.27 & 0.74 & 26.05 \\
\hline \multirow[t]{3}{*}{ LL18 } & 24 & 0.06 & 2.16 & 0.04 & 1.40 \\
\hline & 30 & 0.25 & 9.00 & 0.20 & 7.04 \\
\hline & 48 & 0.18 & 6.48 & 0.14 & 4.92 \\
\hline \multirow[t]{3}{*}{ LB10 } & 24 & 0.42 & 15.14 & 0.16 & 5.63 \\
\hline & 30 & 0.53 & 19.10 & 0.57 & 20.07 \\
\hline & 48 & 0.71 & 25.59 & 0.61 & 21.47 \\
\hline \multirow[t]{3}{*}{ ST A } & 24 & 0.39 & 14.41 & 0.38 & 13.38 \\
\hline & 30 & 0.47 & 16.58 & 0.49 & 16.90 \\
\hline & 48 & 0.77 & 27.39 & 0.75 & 26.06 \\
\hline
\end{tabular}

hydrolyzed pGlu from pGlu-alanine peptide. This result was not obtained with $L$. delbrueckii subsp. bulgaricus 10, L. delbrueckii subsp. lactis 18 or S. thermophilus A. Williams and Banks (1997) detected aminopeptidase activity on pyroglutamil p-nitro anilide substrate by cell lysates from cultures of lactobacilli (which also included two L. helveticus strains) isolated from Cheddar cheese nonstarter microflora. Using cell lysates, Williams et al. (1998) confirmed pyrase activity in L. helveticus and in many mesophilic lactobacilli species, whereas they did not detect this activity in L. delbrueckii subsp. bulgaricus or L. delbrueckii subsp. lactis. Laan et al., 1998 also detected pyrase activity in Lactobacillus casei, Lactobacillus plantarum, and Lactococcus lactis, thus confirming previous observations by Exterkate and Stadhouders (1971).

\section{CONCLUSIONS}

pGlu is a cyclic amino acid, and its content is high in long-ripened cheeses made with starters containing thermophilic LAB (Mucchetti et al., 2000). Despite many studies on the pharmacological properties of pGlu, no data are available on the nutritional and/or pharmacological relevance of the amount of pGlu ingested with hard-cooked cheeses or other foods.

In a previous paper (Mucchetti et al., 2000), the presence of pGlu in different varieties of cheese was evaluated, and some hypotheses as to its formation were made. The present paper provides additional information on the role of thermophilic LAB in producing pGlu. The late appearance of pGlu in hard long ripened cheeses made it necessary to develop a system to accelerate cooked mini-cheese production and ripening in order to demonstrate in vivo pGlu production by the starter microflora. The strains used to make starters showed the ability to produce pGlu in mini-cheeses according to the following order: L. helveticus, L. delbrueckii subsp. bulgaricus, S. thermophilus, and L. delbrueckii subsp. lactis.

The association of glutamine with pGlu cyclase activity was demonstrated in vitro in the four thermophilic lactic species, and aminopeptidase activity was only detected in $L$. helveticus. It can thus be assumed that pGlu formation in long-ripened cooked cheese may depend on thermophilic LAB.

\section{REFERENCES}

Akita, S., K. Tanaka, and S. Kinoshita. 1959. Enzymatic dehydration of L-glutamic acid. Biochem. Biophys. Res. Commun. 1:179-181.

Alais, C. 1984. Science du lait. Principes des techniques laitieres. 4th Ed. S.E.P.A.I.C., Paris.

IDF. 1982. Cheese and Processed cheese. Determination of the total solids content (Reference Method) Provisional IDF Standard 4A:1982. International Dairy Federation. Brussels.

IDF. 1972. Cheese. Determination of chloride content (Reference Method) IDF Standard 17A: 1972. International Dairy Federation. Brussels.

Awadé, A. C., Ph. Cleuziat, T. H. Gonzales, and J. Robert-Baudouy. 1994. Pyrrolidone carboxyl peptidase (PCP): an enzyme that removes pyroglutamic acid (pGLU) from pGlu-peptides and pGluproteins. Proteins Struct. Funct. Genet. 20:34-51.

Beani, L., C. Bianchi, P. G. Baraldi, S. Manfredini, and G. P. Pollini. 1990. Protection by pyroglutamic acid and some of its newly synthesized derivatives against glutamate-induced seizures in mice. Arzneim-forsch. 40(11):1187-1191.

Beni, M., D. E. Giampietro-Pellegrini, and F. Moroni. 1988. A new endogenous anxiolytic agent: L-pyroglutamic acid. Fundam. Clin. Pharmacol. 2(2):77-82.

Borghi, D. 1999. D-amminoacidi come markers di stagionatura e di processo nel formaggio Grana Padano. Ph.D. Diss. in Food Science and Technology at University of Parma, Italy.

Bouzas, J., C. A. Kantt, F. Bodyfelt, and J. A. Torres. 1991. Simultaneous determination of sugars and organic acids in Cheddar cheese by High Performance Liquid Chromatography. J. Food Sci. 56:276-278. 
Chen, G., and J. B. Russel. 1989. Transport of glutamine by Streptococcus bovis and conversion of glutamine to pyroglutamic acid and ammonia. J. Bacteriol. 171:2981-2985.

Exterkate, F. A., and J. Stadhouders. 1971. Pyrrolidone carboxylyl peptidase activity in bitter and non-bitter strains of Streptococcus cremoris. Neth. Milk Dairy J. 25:240-245.

Ferranti, P., E. Itolli, F. Barone, A. Malorni, G. Garro, P. Laezza, L. Chianese, F. Migliaccio, V. Stingo, and F. Addeo. 1997. Combined high-resolution chromatographic technique (FPLC and HPLC) and mass spectrometry-based identification of peptides and proteins in Grana Padano cheese. Lait. 77:683-697

Gatti, M., M. E. Fornasari, G. Mucchetti, F. Addeo, and E. Neviani. 1999. Presence of peptidase activities in different cheese varieties. Lett. Appl. Microbiol. 28:368-372.

Gatti, M., M. E. Fornasari, G. Mucchetti, F. Addeo, and E. Neviani. 2000. Crescita di batteri lattici e cinetica di rilascio di attività enzimatiche in formaggi a pasta dura prodotti con diversi cicli termici di caseificazione. Sci. Techn. Latt. Casear. 51:65-75.

Giraffa, G., L. Rossetti, G. Mucchetti, F. Addeo, and E. Neviani. 1998. Influence of the temperature gradient on the growth of thermophilic lactobacilli used as natural starters in Grana cheese. J. Dairy Sci. 81:31-36.

Gripon, J. C., M. Desmazeaud, D. Le Bars, and J. L. Bergere. 1975. Etude du role des microrganismes et des enzymes au cours de la maturation des fromages. II. L'influence de la presure commerciale. Lait. 55:502-516.

Laan, H., S. E. Tan, P. Bruinenberg, G. Limsowtin, and M. Broome. 1998. Aminopeptidase activities of starter and non-starter lactic acid bacteria under simulated Cheddar cheese ripening conditions. Int. Dairy J. 8:267-274.

Long, M. V., R. Bizzarro, M. Gatti, and E. Neviani. 1999. The influence of temperature on the autolytic activity of thermophilic lactobacilli. Microbiol. Aliments Nutr. 17:33-38.
Kandler, O., and N. Weiss. 1986. Regular, non sporing Gram-positive Rods. Pages 1208-1260 in Bergey's Manual of Systematic bacteriology. Volume 2. William \& Wilkins Ed. Baltimore MD.

Mirzoian, S. A., M. G. Zalinian, M. G. Balasanian, and A. V. Topchian. 1994. The central vascular and metabolic effects of pyroglutamic acid. Eksp. Klin. Farmakol. 57(1):22-24

Mucchetti, G., F. Locci, M. Gatti, E. Neviani, F. Addeo, A. Dossena, and R. Marchelli. 2000. Pyroglutamic acid in cheese: presence, origin and correlation with ripening time of Grana Padano cheese. J. Dairy Sci. 83:659-665.

Neviani, E., and S. Carini. 1994. Microbiology of Parmesan cheese. Microbiol. Aliments Nutr. 12:1-8.

Panari, G. 1985. L'acido lattico e l'acido piroglutammico nella maturazione del formaggio Parmigiano-Reggiano. Sci. Tec. Latt-Casear. 36:98-109.

Panari, G., M. Mongardi, and M. Nanni. 1988. Determinazione con metodi chimici delle frazioni azotate del formaggio ParmigianoReggiano. Pages 85-95 in Ricerca triennale sulla composizione e su alcune peculiari caratteristiche del formaggio Parmigiano Reggiano. Consorzio del Formaggio Parmigiano-Reggiano Ed., Reggio Emila, Italy.

Van Coillie, E., P. Proost, I. Van Aelst, S. Struyf, M. Polfliet, I. De Meester, D. J. Harvey, J. Van Damme, and G. Opdenakker. 1998. Functional comparison of two human monocyte chemotactic protein-2 isoforms, role of the anin-terminal pyroglutamic acid and processing by CD26/dipeptidyl peptidase IV. Biochem. 37(36):12672-112680.

Williams, A. G., and J. M. Banks. 1997. Proteolytic and other hydrolytic enzyme activities in non-starter lactic acid bacteria (NSLAB) isolated from Cheddar cheese manufactured in the United Kingdom. Int. Dairy J. 7:763-774.

Williams, A. G., X. Felipe, and J. M. Banks. 1998. Aminopeptidase and dipeptidyl peptidase activity of Lactobacillus spp. and nonstarter lactic acid bacteria (NSLAB) isolated from Cheddar cheese. Int. Dairy J. 8:255-266. 